\title{
Metals Contents in Spices and Herbs A vailable on the Egy ptian Market: Assessment of Potential Human Health Risk
}

\author{
Naglaa F. E. Soliman* \\ Department of Environmental Studies, Institute of Graduate Studies and Research, Alexandria University, Egypt
}

\begin{abstract}
Spices and herbs are being used as a diet ingredient often to improve color, aroma and acceptability of food. The contamination of spices with heavy metals may result in the accumulation of these metals in the body organs. The aim of the present study was to investigate $\mathrm{As}, \mathrm{Cu}, \mathrm{Fe}$ and $\mathrm{Zn}$ contents in the most popular spices and herbs that are used in Egyptian cuisine. Ten samples were purchased directly from the local markets in Egypt. Arsenic, Copper, Iron and Zinc contents in the samples were determined by atomic absorption spectrophotometer after acid digestion. The concentration ranges for the studied elements were found as 0.02-0.11, 3.72-21.04, 47.39-1261.21, and 2.14-314.05mg/kg for arsenic, copper, iron, and zinc, respectively. The obtained data compared well with the counterpart data reported internationally. The World Health Organization has given the maximum permissible limits of arsenic, copper, Iron and Zinc in species, i.e. 1, 50, 300 and $100 \mathrm{mg} / \mathrm{kg}$, respectively.
\end{abstract}

Keywords: Atomic Absorption Spectroscopy, Heavy Metals, Herbs, Spices.

\section{INTRODUCTION}

Spices and herbs belong to condiments, substances which do not contain nutritive components. Although a few dozen different spice plants are of global importance, many more are used as condiments locally, in the regions of their natural occurrence. Some of them are traded in small quantities and used in ethnic restaurants [1]. "Moreover, in the last three decades, mainly because of their medicinal values, the use of spices and other herbs have increased markedly in most regions of the world, including Europe and North America. For instance, during this period, herbal medication in the USA has grown into an industry worth an average of $\$ 1.5$ billion per year, with projected annual growth of 15\%" [2]. On the other hand, the process of preparation and handling can make them as a source of food poisoning [3]. These spices may easily be contaminated by heavy metals from the soil or aerial depositions as these spices are dried on the ground or on roof tops. Moreover, commercial mills used may also introduce some amount of metals into the seasonings due to wear and tear of the machinery [4].

"Heavy metals are potential environmental contaminants with the capability of finding their way into the food we eat and causing human health problems. They are given special attention throughout the world due to their ubiquitous nature and toxic effects even at very low concentrations" [5]. The accumulation of heavy metals can "have middle term and long term health risks, and strict periodic surveillance of these contaminants is therefore advisable" [6]. As arsenic is

*Address correspondence to these authors at the Department of Environmental Studies, Institute of Graduate Studies \& Research, 163 El Horreya Avenue, Shatby 21526, P.O. Box 832, Alexandria, Egypt;

E-mail: naglaa_farag2007@yahoo.com an element, it is not degraded in the environment. Instead, it may accumulate throughout the food chain. Soil, air, food and water are sources of arsenic [7]. The high level of Arsenic can be due to the use of certain fertilizers and pesticides. Higher concentration of Arsenic in food/spices can cause harmful effect on the skin, lungs, liver and bladder. Its lower effects can cause nausea, vomiting or even damage to the blood vessels [8]. "Copper, which is an element essential for many biological systems, plays an important role in carbohydrate and lipid metabolism. Lack of the recommended dietary allowance for copper may be hazardous to human health" [9]. "The analysis of copper levels in food is of special interest to researchers for these reasons" [10]. Fe is an essential element. It is a constituent of active site of various reproductive hydrogenases, most frequently associated with sulfur containing ligands. Fe together with hemoglobin and ferrodoxin plays a central role of metabolism. Fe facilitates the oxidation of carbohydrates, proteins and fat to control body weight which is an important factor in some diseases (diabetes) [11]. "Zinc is an element found virtually in every cell of the human body and plays vital roles in the development and healthy growth of the human body. Zinc plays an important role in growth and has a recognized action on more than 300 enzymes by participating in their structure or in their catalytic and regulatory action" [12].

However, there is limited data on the levels of these metals in these plants from the Egyptian markets. This work therefore seeks to bridge that gap by providing information on the levels of heavy metals of these most consumed plants. Also, the levels of investigated metals were compared with recommended levels by the international organizations. 


\section{MATERIALS AND METHODS}

\section{Sampling and Sample Preparation}

Eight different powdered samples were purchased at random from local markets in Egypt. The glassware containers used for analysis in this work were washed with detergent and rinsed several times with tap water to remove any contamination due to detergent; then they were soaked overnight in $6 \mathrm{~N} \mathrm{HNO}_{3}$ (Merck) solutions and finally rinsed several times with deionized water.

The samples were carefully opened and dried to constant weight. $1 \mathrm{~g}$ sample was digested with $20 \mathrm{~mL}$ of $2: 1 \mathrm{HNO}_{3} /$ $\mathrm{HClO}_{4}$ (Anal grade), and heated until the evolution of white fumes. Where necessary more acid mixture was added and the sample digested until the evolution of white fumes marking the end of the digestion process. The digests were filtered into standard $50 \mathrm{~mL}$ volumetric flask and made up to the mark with distilled water.

\section{Analytical Quality Control}

"Three replicate digestions were made for each sample. The average of blank signals was subtracted from analytical signals of digested samples". The accuracy and precision of the digestion procedure was carried out in cumin samples by spiking the analyzed samples with aliquots of metal standard and then reanalyzing the samples. All the spiked samples were digested following the procedure described earlier in triplicates. Percentage of recoveries obtained was 90.05, 91.70, 95.4 and $93.76 \%$ for $\mathrm{As}, \mathrm{Zn}, \mathrm{Fe}$ and $\mathrm{Cu}$, respectively and the relative standard deviations (RSDs) of replicates were less than $10 \%(4.9,3.5,4.45$ and 3.78) for As, $\mathrm{Zn}, \mathrm{Fe}$ and $\mathrm{Cu}$, respectively. The detection limit of the method for each metal was As $0.006 \mathrm{mg} / \mathrm{kg}, \mathrm{Cu} 0.029 \mathrm{mg} / \mathrm{kg}$, Fe 0.048 $\mathrm{mg} / \mathrm{kg}$ and $\mathrm{Zn} 0.035 \mathrm{mg} / \mathrm{kg}$.

\section{Instrumentation}

AAs measurements were performed with a SHIMADZU AA6650 atomic absorption spectrophotometer equipped with a deuterium background corrector. An atomizer with an air/acetylene burner head was used for determining all the investigated metals. "All instrumental settings were those recommended in the manufacturer's manual book". The wavelengths $(\mathrm{nm})$ used for the determination of the analytes were as follows: As (193.7), $\mathrm{Cu}$ (324.8), $\mathrm{Zn}$ (213.9) and $\mathrm{Fe}$ (248.3). A standard solution for each metal under investigation was provided by suitable internal chemical standards (Merck Chemicals, Germany). Instruments were calibrated using sets of at least five standards covering the range of concentrations encountered in the literature. All calibration curves showed good linearity $(r>0.99)$. Arsenic was measured based on the following Hydride generation conditions: quartz cell, $16 \mathrm{~cm}$ path length, $90.7 \mathrm{~cm}$ i.d., electrothermal heating, cell temperature, $900^{\circ} \mathrm{C}$, carrier gas (argon) flow rate. $50-100 \mathrm{~mL} / \mathrm{min}$. reducing agent $(0.2 \%$ (w/v) $\mathrm{NaBH}_{4}$ in $0.05 \%$ (w/v) sodium hydroxide solution) flow rate, $5-7 \mathrm{~mL} / \mathrm{min}$, and $\mathrm{HCl}$ flow rate, 9-11 $\mathrm{mL} / \mathrm{min}$ [13] using Shimadzu Hydride Vapor Generator model: HVG-1.

\section{RESULTS AND DISCUSSION}

$\mathrm{As}, \mathrm{Cu}, \mathrm{Fe}$ and $\mathrm{Zn}$ analyses have been performed on eight common spices and herbs available at local markets in Egypt and the outcome has been presented in Table 1. The values of metal concentration were compared with maximum permis-sible standard concentration of 1, 50, 300 and 100 $\mathrm{mg} / \mathrm{kg}$ respectively as recommended by the World Health Organization (WHO) [14] and with the counterpart data reported internationally (Table $\mathbf{2}$ ).

\section{Arsenic}

The concentration of arsenic in the investigated samples ranged from 0.02 in paprika, to $0.11 \mathrm{mg} / \mathrm{kg}$ in cloves (Fig. 1). The concentrations of arsenic in all the analyzed samples are well within the permissible limits set by WHO [14] $(1 \mathrm{mg} / \mathrm{kg})$. It was very well below the limit and may be considered tolerable.

\section{Copper}

Results in Fig. (2) showed that the highest value of 21.04 $\mathrm{mg} / \mathrm{kg}$ for $\mathrm{Cu}$ was registered for hot red pepper, whiles paprika recorded the lowest value of $3.72 \mathrm{mg} / \mathrm{kg}$. All the investigated samples recorded values which were lower than half the WHO limit for $\mathrm{Cu}$ in the spices. "Therefore, the $\mathrm{Cu}$ levels of the samples are relatively very tolerable. Ozkutlu et al [15] reported a range of 3 to $11 \mathrm{mg} / \mathrm{kg}$ for $\mathrm{Cu}$ levels in some spices whiles a previous work reported $6-17 \mathrm{mg} / \mathrm{kg}$ " [16].

\section{Iron}

"Thus Iron has a relatively high WHO level in foods". However, hot red pepper, cloves, parsley and black pepper had Fe levels of, 1361.21, 1180.54, 1230.18 and 452.13

Table 1. Levels (mg/kg) of selected metals in spices samples consumed in Egypt.

\begin{tabular}{|c|c|c|c|c|}
\hline As & & Cu & Fe & 47.39 \\
\hline Min & 0.02 & 3.72 & 361.21 & 314.05 \\
\hline Max & 0.11 & 21.04 & 620.02 & 132.98 \\
\hline Mean & 0.05 & 8.27 & 541.36 & 133.91 \\
\hline SD & 0.03 & 5.73 & 300 & 100 \\
\hline
\end{tabular}




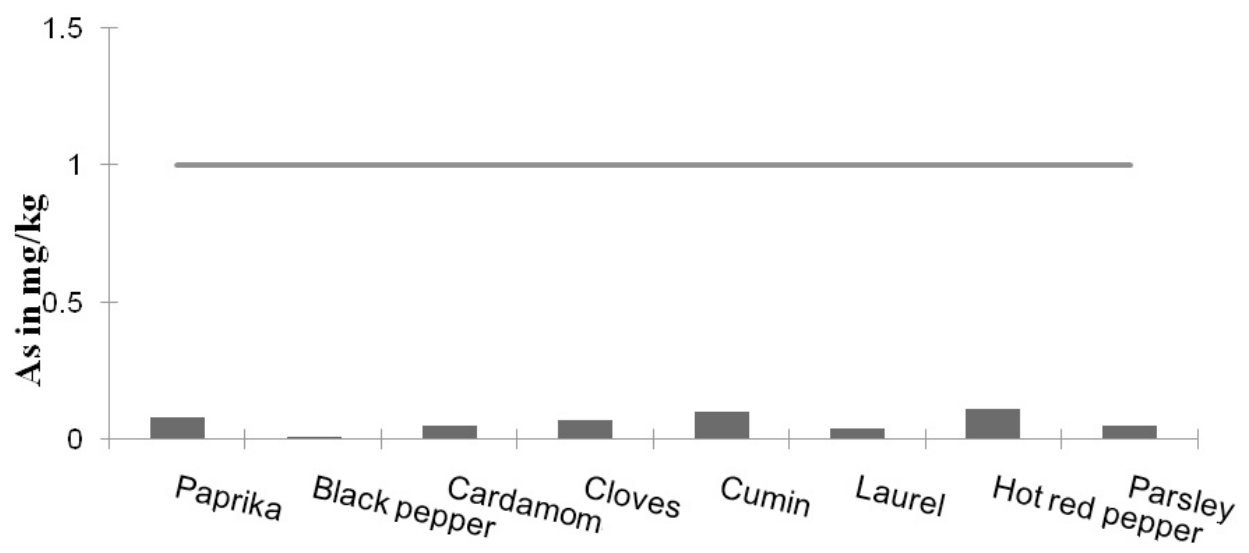

Fig. (1). Levels of Arsenic in different spices.

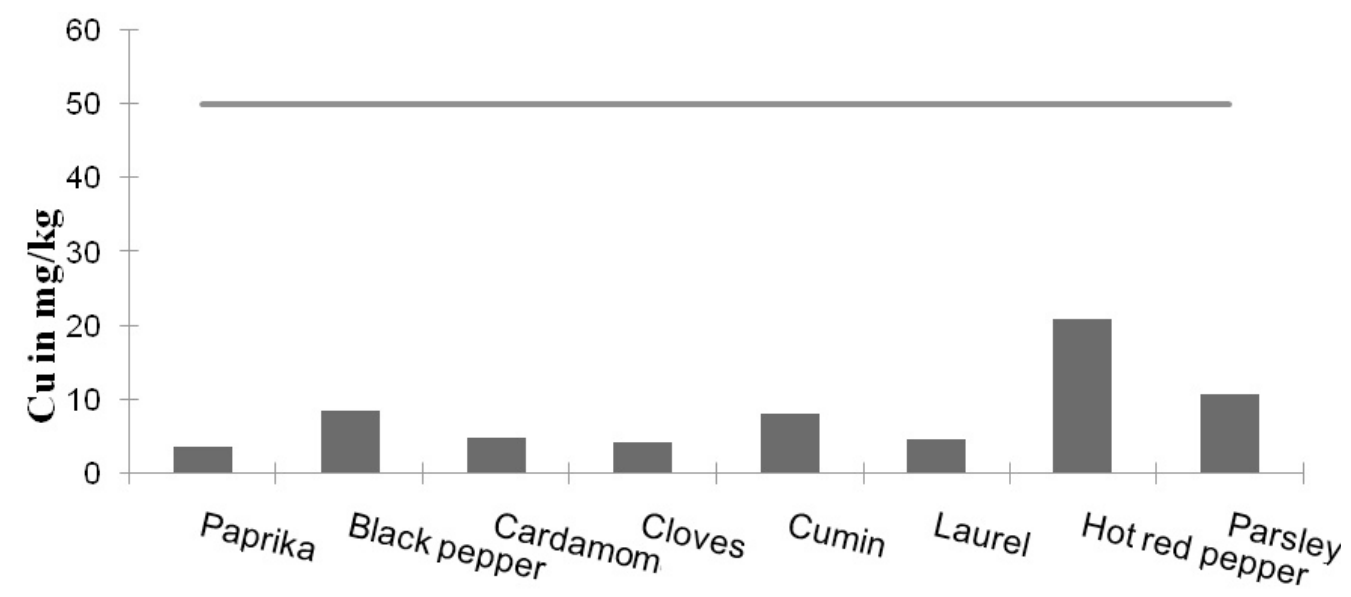

Fig. (2). Levels of Copper in different spices.

Table 2. International comparison of the data.

\begin{tabular}{|c|c|c|c|c|}
\hline Reference & As $(\mathbf{m g} / \mathbf{k g})$ & $\mathbf{C u}(\mathbf{m g} / \mathbf{k g})$ & Fe (mg/kg) & Zn (mg/kg) \\
\hline \hline This work & $0.02-0.11$ & $3.72-21.04$ & $47.39-1361.21$ & $2.14-314.05$ \\
\hline$[1]$ & NA & $4.2-9.12$ & $19.4-971.4$ & $2.4-34.60$ \\
\hline$[4]$ & NA & $0.9-10.10$ & NA & NA \\
\hline$[8]$ & $0.7-1.5$ & $2.3-19.69$ & $30-945.3$ & $5.2-83.7$ \\
\hline$[21]$ & NA & $3.8-35.4$ & $144.5-1260$ & NA \\
\hline$[22]$ & NA & $9-44$ & $56-650$ & $6.1-47$ \\
\hline$[23]$ & NA & $10.5-22.5$ & NA & NA \\
\hline$[24]$ & $<0.07-0.37$ & NA & $115.25-1265.76$ & NA \\
\hline$[25]$ & NA & ND-0.9 & NA & NA \\
\hline
\end{tabular}

NA; Not available

ND, Not detected

$\mathrm{mg} / \mathrm{kg}$ respectively, which are distinctly beyond the WHO limit. The high levels of iron could be due to contamination during milling. Research indicates that grinding of spices in commercial mills contaminates them to about between 3 and 5 folds, due to wear and tear of the machine parts [17]. On the other hand, cumin, laurel, cardamom and paprika Fig. (3). may be considered as alternate sources of Fe, "as they recorded levels below that of the WHO but were yet rich in $\mathrm{Fe}$, as far as this study report is concern".

Zinc

In case of zinc, there was a large variation in concentration for all the samples ranging from $2.14 \mathrm{mg} / \mathrm{kg}$ for paprika and $314.05 \mathrm{mg} / \mathrm{kg}$ for cumin (Fig. 4). The 
obtained results showed higher values than those values (5974) and (7.2-16.3) $\mathrm{mg} / \mathrm{kg}$ reported by Nkansha and Amoako [18] and Iwegbue et al. [19] respectively. "It is therefore imperative to perform routine monitoring on the levels of $\mathrm{Zn}$ in these well-patronized spices so as to avert encountering prolific zinc toxicity"[18].

The relatively high level of the essential elements iron (Fe) and zinc $(\mathrm{Zn})$ in this work corroborates the result of Onianwa et al. [20] "and reflects the normal composition expected of plant-derived products, which most of the samples are. Plant foods and plant derived foods contain iron in the form of metalloproteins, plant ferritins, iron present in the sap and iron complexed to structural components or storage compounds predominantly as phytates".

\section{CALCULATION OF THE DAILY DIETARY INTAKE}

Heavy metals and As are the subjects of many studies because of their toxicity, persistence in the environment and bioaccumulative ability. Indeed, they are accumulated through food chains up to toxic concentrations; therefore, they can pose an adverse potential threat both for animal and human health [27].
As consumption of spices is a possible source of heavy metals accumulation in human body, there is a great interest in estimation of the daily dietary intakes of these metals through spices consumption.

The daily dietary intake (mg/day/person) was calculated based on these suppose:

1) The human weight is $50 \mathrm{~kg}$

2) The human intake from spices per day is $20 \mathrm{~g}$

Where

The daily dietary intake (mg/day/person) $=$ A X B

A is the average quantity of spices in gram consumed per individual per day

B is the concentration of metal $(\mathrm{mg} / \mathrm{kg})$ in studied samples [22].

The recommended dietary allowances (RDA) as $\mathrm{mg} /$ day/person for copper, iron and zinc are 2, 18 and 15, respectively [28]. The daily dietary intake values calculated for spices examined in present study were lower than the Food and Nutrition Board of the National Academy of Sciences, United States recommendations given above.

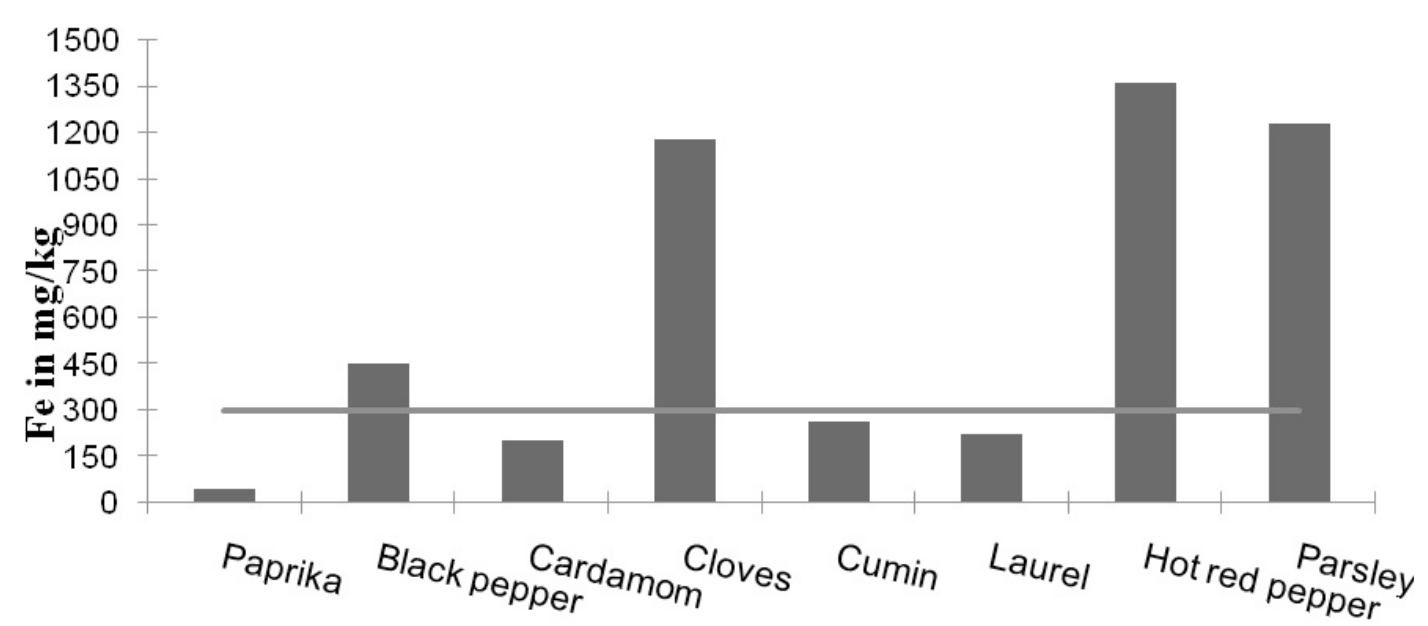

Fig. (3). Levels of Iron in different spices.

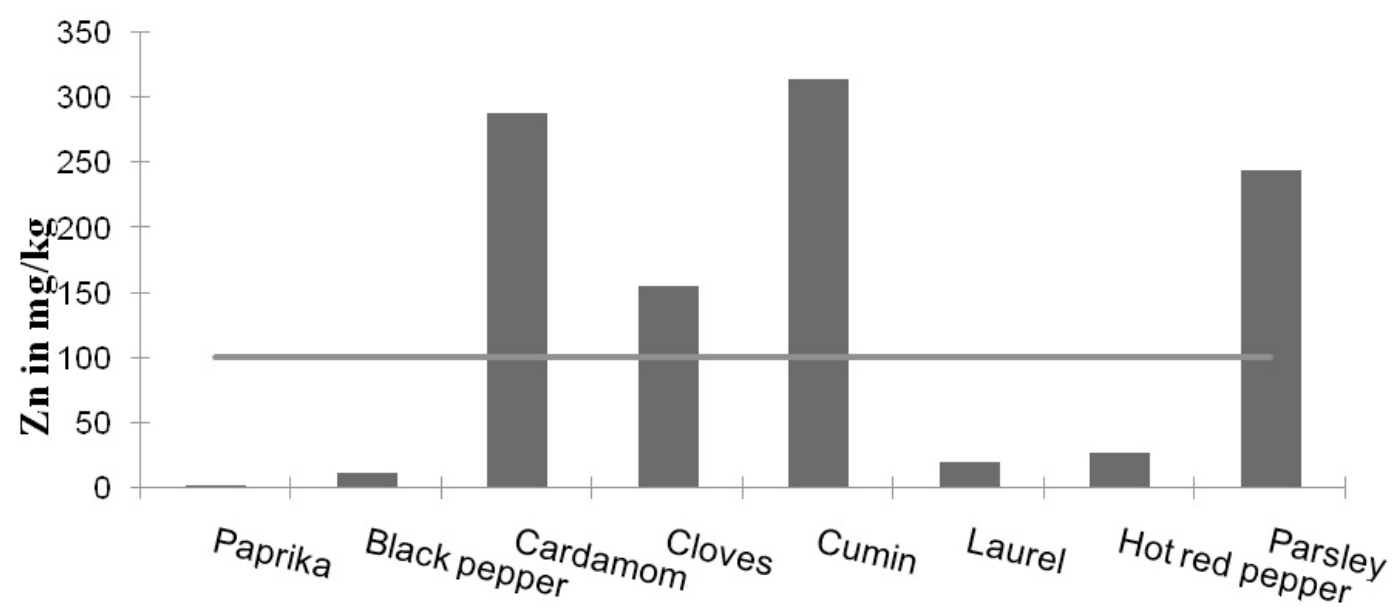

Fig. (4). Levels of Zinc in different spices. 
Table 3. Target hazard quotients (THQs) and total target hazard quotients (TTHQs) for metals by consumption of spices.

\begin{tabular}{|c|c|c|c|c|c|}
\hline \multirow{2}{*}{ TTHQs } & \multicolumn{3}{|c|}{ THQs } & \multicolumn{2}{c|}{ Sample } \\
\cline { 2 - 6 } & As Cu & & Zn & Fe & Paprika \\
\hline \hline 0.08 & 0.014 & 0.037 & 0.003 & 0.027 & Black pepper \\
\hline 0.39 & 0.034 & 0.086 & 0.008 & 0.258 & Cardamom \\
\hline 0.39 & 0.027 & 0.049 & 0.196 & 0.115 & Cloves \\
\hline 0.90 & 0.075 & 0.043 & 0.106 & 0.675 & Cumin \\
\hline 0.47 & 0.020 & 0.082 & 0.214 & 0.152 & Laurel \\
\hline 0.22 & 0.027 & 0.048 & 0.014 & 0.126 & 0.778 \\
\hline 1.03 & 0.020 & 0.210 & 0.018 & 0.703 & Hot red pepper \\
\hline 1.01 & 0.034 & 0.107 & 0.166 & Parsley \\
\hline
\end{tabular}

The weekly tolerable intake value of As is $7 \mu \mathrm{g} / \mathrm{kg}$ body weight [29]. On the other hand it is stated $12-25 \mu \mathrm{g} / \mathrm{day}$ As is enough to meet the requirements [30]. It is not possible to provide As by consuming only these species.

\section{HUMAN RISK ASSESSMENT ANALYSIS}

The health risks from consumption of spices were assessed based on the target hazard quotient (THQ). The THQ is a ratio of determined dose of a pollutant to a reference dose level. If the ratio is less than 1 , the exposed pollution is unlikely to experience obvious adverse effects. The method of estimating risk using THQ was provided in the USEPA region III risk-based concentration table (USEPA 2007) [31] and it is described by the following equation:

$$
\text { THQ=,,EF-r.x ED x FI x MC-RfD x BW x AT. }
$$

Where THQ target hazard quotient; EFr is the exposure frequency (365 days/year); ED is the exposure duration over a lifetime (70 years), FI is the mean ingestion rate (20g/person/day); MC is the metal concentration in spices $(\mu \mathrm{g} / \mathrm{g}$, on wet weight), , and AT is the average life time (70 years x 365 days/year); RfD of the oral reference dose for $\mathrm{Fe}, \mathrm{Cu}, \mathrm{Zn}$, and As suggested by the USEPA (2011) [32] 0.7, $0.04,0.3$ and $0.0003 \mu \mathrm{g} / \mathrm{g} / \mathrm{day}$, respectively; $\mathrm{BW}$ is the average body weight $(50 \mathrm{~kg})$; AT is averaging time for noncarcinogenes (365 days/year x number of exposure years, assuming 70 years in this study).

The THQ has been recognized as a useful parameter for the evaluation of risk associated with the consumption of metal contaminated food [33]. The target hazard quotients (THQs) values of $\mathrm{As}, \mathrm{Cu}, \mathrm{Fe}$, and $\mathrm{Zn}$ for the investigated samples do not exceed one indicating that there is no health risk from consuming these spices (Table 3). However, the total target hazard quotients (TTHQs) ranged from 0.08 to 1.03 for the consumption of spices (Table 3). The TTHQs value caused by consuming hot red pepper (1.03) and parsley (1.01) were quite higher than 1 , and likely will pose a potential risk to the local inhabitants through its consumption.

\section{CONCLUSION}

Metals are present in spices and herbs at different concentrations, which in some cases exceeded the permissible levels. Grinding of spices in commercial mills contaminates them due to wear and tear of the machine parts. In general, routine check and frequent analysis of foodstuff is required to avoid the risk of exceeding the intake beyond the tolerance limits standards. Moreover, the results of this work can also be used to understand the chemical quality of spices, and to evaluate the possible risk associated with their consumption.

\section{CONFLICT OF INTEREST}

The author confirms that this article content has no conflict of interest.

\section{ACKNOWLEDGEMENTS}

Declared none.

\section{REFERENCES}

[1] Krejpcio Z, Król1 E, Sionkowski S. Evaluation of heavy metals contents in spices and herbs available on the polish market. Pol J Environ Stud 2007; 16: 97-100.

[2] Abebe W. potential health benefits of spices used in ethiopian cuisines. Ethiop Med J 2006; 44 (2): 133-8.

[3] Sherman WP, Billing J. Antimicrobial functions of spices: why some like it hot. Q Rev Biol 1998; 73 (3): 1-47.

[4] Darko1 B, Ayim I, Voegborlo RB. Heavy metal content in mixed and unmixed seasonings on the Ghanaian market. Afr J Food Sci 2014; 8 (1): 14-9.

[5] Das A. Metal ion induced toxicity and detoxification by chelation therapy. $1^{\text {st }}$ ed. A text book on medical aspects of bioinorganic chemistry, CBS, Delhi, 1990; pp. 17-58.

[6] Cabrera C, Lorenzo ML, Lopez CM. Lead and cadmium contamination in dairy products and its repercussion on dietary intake. J Agric Food Chem 1995; 43: 1605-9.

[7] Gehle K. Arsenic Toxicity. ATSDR Case Studies in Environmental Medicine, Agency for Toxic Substances and Disease Registry (ATSDR), Course WBCBDV1576; US department of health and human development, 2009.

[8] Inam F, Deo S, Narkhede N. Analysis of minerals and heavy metals in some spices collected from local market. IOSR- J Pharm Biol Sci 2013; 8(2): 40-3. 
[9] Silva EL, Roldan PS, Giné MF. Simultaneous preconcentration of copper, zinc, cadmium, and nickel in water samples by cloud point extraction using 4-(2-pyridylazo)- resorcinol and their determination by inductively coupled plasma optic emission spectrometry. J Hazard Mater 2009; 171: 1133-8.

[10] Soylak M, Cihan Z, Yilmaz E. Evaluation of trace element contents of some herbal plants and spices retailed in Kayseri, Turkey. Environ Monit Assess 2012; 184: 3455-61

[11] Rajukar NS, Pardesi BM. Analysis of some herbal plants from India used in the control of diabetes mellitus by NAA and AAS techniques. Appl Radiat Isot 1997; 48: 1059-62.

[12] Salgueiro MJ, Zubillaga MB, Lysionek AE, et al. The role of zinc in growth and development of children. Nutr 2002; 18: 510-9.

[13] Ruangwises S, Saipan P, Tengjaroenkul B, et al. Total and inorganic arsenic in rice and rice bran purchased in Thailand. J Food Protect 2012; 75: 771-4.

[14] WHO. Evaluation of certain food additives and contaminants. WHO Technical Report Series 776. Geneva: World Health Organization 1989.

[15] Ozkutlu F, Sekeroglu N, Kara SM. Monitoring of Cadmium and Micronutrients in Spices Commonly Consumed in Turkey. Res J Agr Biol Sci 2006; 2(5): 223-6.

[16] Ozkutlu F, Kara SM, Şekeroğlu N. Heavy metals, micronutrients, mineral content, toxicity, trace elements. International Symposium on Medicinal and Nutraceutical Plants , ISHS Acta Horticul 1997; p. 756.

[17] Janitha PP, Chaman DKI, Samarajeewa U. Iron contamination during grinding of spices. J Natl Sci Coun 1988; 16(1): 105-14.

[18] Nkansah MA, Amoako CO. Heavy metal content of some common spices available in markets in the Kumasi metropolis of Ghana. Am J Sci Ind Res 2010; 1(2): 158-63.

[19] Iwegbue CMA, Overah CL, Ebigwai JK, et al. Heavy metal contamination of some vegetables and spices in Nigeria. Int $\mathrm{J}$ Biol Chem Sci 2011; 5(2): 766-73.

[20] Onianwa PC, Adetola IG, Iwegbue CMA, et al. Trace heavy metals composition of some Nigerian beverages and food drinks. Food Chem 1999; 66: 275-9.
[21] Divrikli U. Horzum N, Soylak M, et al. Trace heavy metal contents of some spices and herbal plants from western Anatolia, Turkey. Int J Food Sci Tech 2006; 41; 712-6.

[22] Mubeen H, Naeem I, Taskeen A, et al. Investigations of Heavy Metals in Commercial Spices Brands. NY Sci J 2009; 2(5): 20-6.

[23] Ibrahim GI, Hassan LM, Baban SO, et al. Effect of Heavy Metal Content of some Common Spices Available in Local Markets in Erbil City on Human Consumption. Raf J Sci 2012; 23(3): 106-14.

[24] Osati S, Davari A, Safafar H, et al. Arsenic intakes from spices and sheep tail (Donbeh) in a high oesophageal cancer area: Pilot study from Iran. J Paramed Sci 2012; 4(3): 31-4.

[25] Umar MA, Salihu ZO. Heavy metals content of some spices available within FCT-Abuja, Nigeria. Int J Agric Food Sci 2014 4(1): 66-74.

[26] Sharma N, More BP, Bhandari D, et al. Analysis of Heavy Metals Content in Spices Collected from Local Market of Mumbai by using Atomic Absorption Spectrometer. GJRA 2014; 5: 56-7.

[27] Petkovšek SA, Grudnik ZM, Pokorny B. Heavy metals and arsenic concentrations in ten fish species from the Šalek lakes (Slovenia): assessment of potential human health risk due to fish consumption. Environ Monit Assess 2012; 184: 2647-62.

[28] National Research Council. Food, Nutrition Board, National Academy of Sciences Recommended Dietary Allowances, 10th edn. Washington, DC: National Academy Press 1989.

[29] Aras NK, Ataman OY. Trace Element Analysis of Food and Diet. Cambridge, UK; RSC Publishing 2006.

[30] Berdanier CD. Advanced Nutrition. Boca Raton: Florida; 1998.

[31] USEPA. Integrated risk information system database. PA Washington, DC; Philadelphia 2007.

[32] USEPA. Risk based concentration table. 2011 http://www.epa.gov. reg3 hwmd/risk/human/index.htm

[33] Abdallah MAM. Bioaccumulation of Heavy Metals in Mollusca Species and Assessment of Potential Risks to Human Health. Bull Environ Contam Toxicol 2013; 90, 552-7.

Received: July 22, 2014

Revised: November 06, 2014

Accepted: November 10, 2014

(C) Naglaa F. E. Soliman; Licensee Bentham Open.

This is an open access article licensed under the terms of the Creative Commons Attribution Non-Commercial License (http://creativecommons.org/licenses/ by-nc/3.0/) which permits unrestricted, non-commercial use, distribution and reproduction in any medium, provided the work is properly cited. 